\title{
Characterization of Biofilms and Mineralogical Scale in Underground Injection Well Disposal of Landfill Leachate and Industrial Wastewater Streams
}

\author{
Daniel E. Meeroff ${ }^{*}$, Bishow Shaha1, Frederick Bloetscher' ${ }^{1}$, Nwadiuto Esiobu ${ }^{2}$, Brian Mercer ${ }^{2}$, \\ Donald McCorquordale ${ }^{3}$, Ramana Kari ${ }^{4}$, Michael Bennett ${ }^{5}$
}

\author{
${ }^{1}$ Department of Civil, Environmental \& Geomatics Engineering, Florida Atlantic University, Boca Raton, FL, USA \\ ${ }^{4}$ Department of Biological Sciences, Florida Atlantic University, Sanson Life Sciences, Boca Raton, FL, USA \\ ${ }^{3}$ Applied Biotech Inc., Plantation, FL, USA \\ ${ }^{4}$ Solid Waste Authority of Palm Beach County, West Palm Beach, FL, USA \\ ${ }^{5}$ AECOM/URS, West Palm Beach, FL, USA \\ Email: *dmeeroff@fau.edu, bshaha2015@fau.edu, fbloetsc@fau.edu, nesiobu@fau.edu, Brian.mercer@fau.edu, \\ Info@appliedbiotech.net,rkari@swa.org, Michael.Bennett@aecom.com
}

\begin{abstract}
How to cite this paper: Meeroff, D. E., Shaha, B., Bloetscher, F., Esiobu, N., Mercer, B., McCorquordale, D., Kari, R., \& Bennett, M. (2019). Characterization of Biofilms and Mineralogical Scale in Underground Injection Well Disposal of Landfill Leachate and Industrial Wastewater Streams. Journal of Geoscience and Environment Protection, 7, 69-91.
\end{abstract}

https://doi.org/10.4236/gep.2019.711006

Received: October 8, 2019

Accepted: November 11, 2019

Published: November 14, 2019

Copyright $\odot 2019$ by author(s) and Scientific Research Publishing Inc. This work is licensed under the Creative Commons Attribution International License (CC BY 4.0).

http://creativecommons.org/licenses/by/4.0/ (c) (i) Open Access

\begin{abstract}
Deep-well injection is a cost-effective alternative for industrial wastewater disposal, given the appropriate geology. Fouling of injection well tubing by biofilm or scale is common and reduces the effective diameter of the pipe, which results in increased wellhead pressure and lower injectivity. A detailed microbiological composition of biofilms and abiotic fingerprints use of mineral scale from an injection well has not been reported before. Therefore, biofilm and mineral scale samples from three depth intervals within a deep injection well (surface zone, D1= 0 - $61 \mathrm{~m}$; intermediate zone, D2 = $62-457 \mathrm{~m}$; and above the injection zone, D3 $=458-884 \mathrm{~m}$ ) with recurrent biofilm development were collected to characterize the mineral composition and microbial community DNA. X-ray diffraction (XRD) analysis of the solids confirms the composition of the solids collected was mostly calcium carbonate $\left(\mathrm{CaCO}_{3}\right)$ with minor contributions from common mineral salts. Microbiological fingerprinting suggests that methanogenic archaea and sulfatereducing bacteria both of which are anaerobic biofilm producers were the most prevalent members of the prokaryotic community at all sampled depths. $M e$ thanosarcinae spp. increased with increasing depths, unlike other archaea. A non-pathogenic biofilm-producing Entamoeba dispar was the most prevalent member of the microbial domain (>30\%) in all samples but was highest at the middle depth. The Chao alpha diversity indices for bacteria, viruses, and
\end{abstract}


protozoans were highest at the shallow depth and gradually declined with increasing depth. The prevalent species above the injection zone depth are not barophilic organisms that thrive at high pressures, rather they are sulfate-reducing bacteria involved in anaerobic dissimilatory sulfate metabolism.

\section{Keywords}

Injection Well, Leachate, Industrial Wastewater Disposal, Biofilm

Microbiology, Well Rehabilitation, Metagenomic Sequencing

\section{Introduction}

Underground injection of liquid wastes is a dependable, low-cost alternative to conventional treatment methods (physical, chemical, and biological) if the appropriate geology is available. Performance of injection wells is critically dependent upon the physico-chemical properties of the waste, and the operational parameters (e.g., injection rates and pressures), as well as the hydrogeologic and geochemical properties of the subsurface (Saripalli et al., 2000). However, fouling of injection wells can lead to catastrophic failure of the industrial wastewater collection and disposal system. Fouling can take the form of biofilms, mineral scale deposits, or both and can potentially reduce the effective diameter of the injection tubing, which results in increased wellhead pressure and reduced injectivity by as much as $50 \%$ within a year (AECOM, 2019).

Biofilms, which are complex communities of diverse microorganisms embedded in a highly hydrated extracellular matrix that provides structural heterogeneity, are often observed as an unwanted accumulation attached to a surface, such as the inner wall of injection tubing. Key requirements for biofilm development include an active microbial community and interaction with pipe materials (Videla, 2018). The first microorganisms to attach are called "pioneers", which are most commonly facultative anaerobes (Videla, 2018). During biofilm growth, these microorganisms excrete a matrix of extracellular polymeric substances (EPSs), which lead to the formation of a slime layer that connects cells and anchors them to the surface and to each other. These pioneering species are typically acid-formers that reduce the $\mathrm{pH}$ near the pipe wall and can accelerate localized corrosion (Videla, 2018). A depleted oxygen layer forms near the zone of attachment, and an anaerobic environment in which microorganisms such as sulfate-reducing bacteria (SRB) can proliferate because the transport of oxygen into the anaerobic layer of the biofilm is limited by the biological activity in the outer layers (Bloetscher et al., 2002a-c). Sulfur can be reduced by anaerobic bacteria to release hydrogen sulfide, which can significantly increase the susceptibility of the pipe to pitting. This phenomenon can create localized anodes and, in conjunction with abiotic reactions caused by dissimilar metals or pipe defects, can lead to a steady cathodic deterioration over time. Aerobic microorganisms present in the biofilm can also corrode metals directly via oxidation (Videla, 
2018). Over time, the microbial growth forms in layers, growing thicker until the original layer sloughs off, and the process begins again.

From a microbial perspective, biofilms provide an ideal habitat as a source of nutrients, oxygen stratification, resistance to velocity currents, and protection from grazers and biocides (Videla, 2018; Bleotscher et al., 2002a-c; Bloetscher et al., 2010). If left uncontrolled, biofilms can cause pipe damage (corrosion and tubercles) and require pipe replacement or more frequent maintenance. The rate of biofilm deposit formation is a function of nutrient availability, EPS production, the volume of flow, flow rate, turbulence and precipitation mechanism (Blenkinsopp \& Costerton, 1991; McLaughlan, 2002). Biofilm deposits (soft matrix) changes into a semi-porous structure with embedded mineral deposit and solid particles that become firmly attached to the adjacent pipe surfaces (VanGulck \& Rowe, 2004).

Mineral scale deposits are most commonly comprised of calcium carbonate $\left(\mathrm{CaCO}_{3}\right)$ in industrial wastewater collection and disposal systems due to the supersaturated nature of calcium and carbonate. Analyses (X-ray diffraction, elemental analysis) of mineral deposits identified calcite to be the predominant species in the mineral deposit along with some salts and other impurities (Maliva et al., 2000; Mulla, 2006; Shaha, 2016; Shaha et al., 2016; Shaha et al., 2019). Mineral deposits likely begin to form around a nucleus of silt, sand, and/or biofilms, although the precise trigger mechanism is not known. Scale formations are largely dependent on the flow regime, temperature, $\mathrm{pH}$, and degasification of carbon dioxide as well as the strength of key water quality parameters (total solids, alkalinity, calcium) (Shaha et al., 2019; Shaha, 2016; Mayer et al., 2014; Mayer et al., 2013; Levine et al., 2005; Fleming et al., 1999).

Advances in the analysis of metagenomes have allowed environmental microbiologists to simultaneously identify microorganisms and compute their relative abundance in a biofilm (Hwang et al., 2012). In multi-domain communities, whole genome shotgun sequencing protocols and analysis allow the detection and quantification of target genes and all DNA-based life forms of various domains-bacteria, algae, fungi, protozoans and viruses in biofilms, as described in Leddy et al. (2017). Characterization of community fingerprints in biofilms can establish system benchmarks and provide information on how to improve performance and control fouling. In addition, TSS of the injected fluid and gas condensate emulsion in the injected fluid play an important role in clogging the injection horizon by reducing the formation permeability and thus the injectivity of the injection well (Boulding \& Jones, 1990; Stow \& Johnson, 1990; Melcer et al., 1996; Ochi \& Vernoux, 1996).

Detailed biological and abiotic fingerprints of biofilms and mineral scale from inside a deep injection well have not been conducted before. Therefore, the focus of this study is to collect biofilm and mineral scale samples from three different depth intervals within the well (surface zone, D1 $=0-61 \mathrm{~m}$; intermediate zone, D2 = $62-457 \mathrm{~m}$; and above the injection zone, D3 = $458-884 \mathrm{~m}$ ) during a routine brushing and backflushing event of a deep injection well used for industrial 
wastewater disposal. Microbiological analysis will provide useful information about the sub-surface microbiota in the injection well whereas mineralogical analysis along with water quality parameters will provide insight relating to the scaling potential as well as the chemical composition of the biofilm. These techniques will be used to determine the major causes of biofilm and chemical scale formation in the injection tubing as a means to identify potential rehabilitation and prevention strategies.

\section{Materials and Methods}

\subsection{Study Site}

The setting for this study was an urban solid waste management facility that provides municipal solid waste (MSW) disposal and recycling services to a population of 1.4 million. The facility has an integrated solid waste management system comprised of a municipal solid waste double-lined landfill, a construction and demolition (C\&D) debris landfill, and a partially closed landfill, a recovered material processing facility, two waste-to-energy (WTE) facilities, a biosolids processing. In 2017, the facility processed total 3.1 million tonnes (13.39 pounds per capita day) of MSW by recycling, combusting, and landfilling approximately $1.4,1.0$, and 0.7 million tonnes of MSW respectively (FDEP, 2017).

The waste disposed of to the MSW landfill includes MSW, a mixture of bottom ash and fly ash from WTE, and inert waste and reject waste from processing of the refuse-derived fuel (RDF). The facility collects leachate and industrial wastewater from the MSW landfills, C\&D, partially closed landfill, as well as industrial wastewater from the biosolids processing facility and the WTE facility to an onsite deep injection well system. The mixed leachate and industrial wastewater streams are disposed of approximately 900 meters (3000 feet) beneath ground surface (Shaha, 2016).

The facility disposes of approximately 34,000 to 64,000 cubic meters (9.0 to 17.0 million gallons) per month of mixed waste streams through deep well injection at an average injection rate of 250 cubic meter per hour (1100 gpm). Historically, observed declines in well injectivity were addressed by replacing 254 $\mathrm{mm}$ (10-inch) diameter carbon steel tubing with new $244 \mathrm{~mm}$ (9 - 5/8 inch) fiberglass reinforced plastic (FRP) tubing in October 2007 to reduce friction as backflushing to attempt to increase injectivity. The installation of FRP tubing increased the injectivity from $0.76-0.80 \mathrm{~m}^{3} / \mathrm{hr} / \mathrm{kPa}(23.0-24.1 \mathrm{gpm} / \mathrm{psig})$ to $1.46-1.48 \mathrm{~m}^{3} / \mathrm{hr} / \mathrm{kPa}(44.5-45.1 \mathrm{gpm} / \mathrm{psig})$ at an injection rate of $237-394$ $\mathrm{m}^{3} / \mathrm{hr}(1045$ - $1735 \mathrm{gpm})$. Even after rehabilitation activities completed in 2016, the injectivity declined to approximately $0.86-1.02 \mathrm{~m}^{3} / \mathrm{hr} / \mathrm{kPa}(26.0-31.0$ $\mathrm{gpm} / \mathrm{psig}$ ) based on an injection rate of $342 \mathrm{~m}^{3} / \mathrm{hr}(1505 \mathrm{gpm})$ in little over a year. Previous downhole video surveys completed as a part of well rehabilitation activities have shown the presence of biofilms and mineral scale of varying thickness on the injection well tubing that potentially reduces injectivity by re- 
ducing the effective diameter and roughness leading to increased wellhead pressure.

\subsection{Sample Collection, Handling, and Storage}

A sampling plan was developed to minimize potential contamination of biofilm samples during the well brushing and backflushing event. Samples and duplicates were collected during the well brushing event at three depth intervals (D1 $=0$ $61 \mathrm{~m}, \mathrm{D} 2=62-457 \mathrm{~m}$, and D3 $=458-884 \mathrm{~m}$ ) corresponding to surface zone, intermediate zone, and above the injection zone. Once the brush reached each target depth, water and brushed particles/biofilm were backflushed to facilitate sample collection (refer to Figure 1).

The sampling hose was replaced with a new, pre-sterilized hose after collecting samples at each depth. The sterilization procedure was as follows: wash thoroughly with liquid detergent soap $\left(\right.$ Liquinox $^{\circledR}$ ) and rinse with at least three volumes of sterile deionized water. The removable valve assembly was taken apart, and the sterilization procedure was followed at each sampling interval. The research team collected two $500 \mathrm{~mL}$ samples in HDPE bottles and two 5-L samples

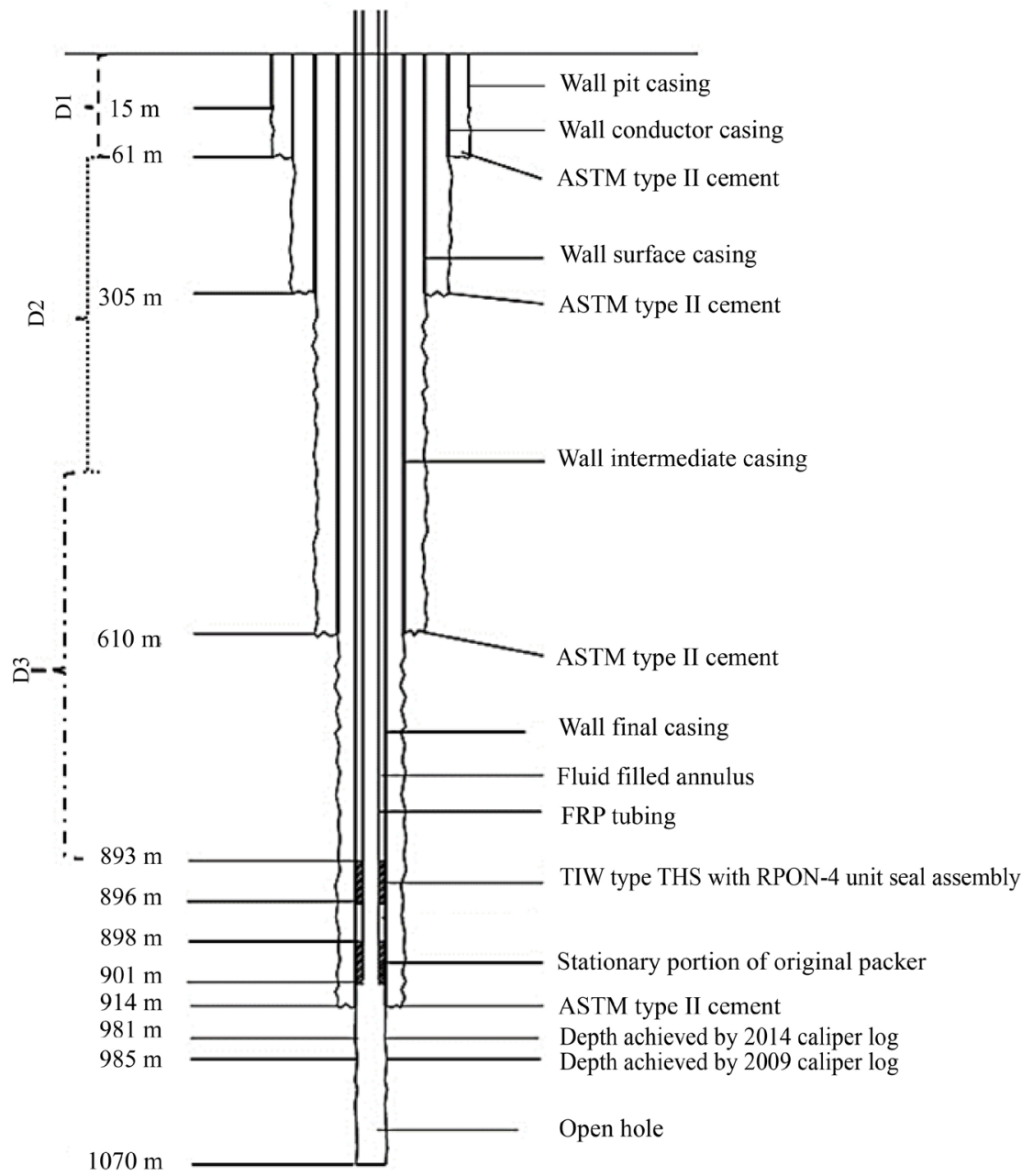

Figure 1. Injection well construction details and sampling zones (AECOM, 2019). 
in wide mouth 9L autoclave sterilized carboys at each depth interval for water quality and microbiological analysis, respectively. In addition, two 18.9-L (5-gallon) buckets were filled with sample from each depth and retained for approximately 10 minutes to allow the brushed particles to settle out. The settled particles were collected from the bottom of the bucket in a $500 \mathrm{~mL}$ HDPE sample bottle for mineralogical analysis. The samples were stored in at $4^{\circ} \mathrm{C}$ immediately after sample collection and transported to the laboratory. All microbiological samples were analyzed with 7 hours of collection since Standard Methods (APHA et al., 2017) recommends analysis hold times of less than 8 - 24 hours. Similarly, water quality and mineralogical analysis were conducted within 48 hours and 7 days of sample collection, respectively, as recommended by Standard Methods (APHA et al., 2017) Equipment blanks were prepared for each set of duplicate samples before sampling took place. An aliquot of $500 \mathrm{~mL}$ of sterile water was poured into the carboy and vigorously shaken. The water was then poured into a sterile amber $1000 \mathrm{~mL}$ bottle for analysis. These equipment blanks also served as reagent blanks.

\subsection{Mineralogical Analysis}

Mineralogical analysis included both water quality analysis of the liquid samples to assess the chemical precipitation potential by calculating saturation indices (Langelier Saturation index: LSI, and Ryzner index: RI) and X-ray diffraction (XRD) analysis to determine the chemical composition.

\subsubsection{Water Quality Analysis}

The initial pH (SM4500-H+ B), specific conductance (SM2510A), conductivity (SM2510B), total dissolved solids (conductivity multiplied by the instrument conversion factor), water temperature (SM2550B), dissolved oxygen (SM4500-O $\mathrm{G})$ and oxidation-reduction potential (SM2580B) of the samples were recorded using a calibrated YSI 556 multiparameter system. Turbidity was measured in the field using a portable Hach 2100Q turbidimeter. Alkalinity (SM 2320 B and total calcium were tested in the laboratory using EDTA titrimetric method (SM 3500-Ca D). Gravimetric solids analyses (TSS, TDS, and VSS) were conducted using SM2540 (APHA et al., 2017). Chloride was measured using Hach digital titrator (Method 8207: Silver Nitrate Method for water, wastewater, and seawater).

\subsubsection{Saturation Indices}

LSI and RI are two commonly used saturation indices to assess $\mathrm{CaCO}_{3}$ precipitation potential (Qasim et al., 2000; Al-Rawajfeh et al. 2005; Luo et al. 2009; Omar et al. 2010; Nia et al. 2010; De Moel et al. 2013). LSI measures the effect of pH on the equilibrium solubility of $\mathrm{CaCO}_{3}$. The $\mathrm{pH}$ of saturation $\left(\mathrm{pH}_{\mathrm{s}}\right)$ is the $\mathrm{pH}$ at which water is saturated with $\mathrm{CaCO}_{3}$. In mathematical terms:

$$
\mathrm{LSI}=\mathrm{pH}-\mathrm{pH}_{\mathrm{s}}
$$

and 


$$
\mathrm{pH}_{\mathrm{s}}=\mathrm{pK}_{2}-\mathrm{pK}_{s}+\mathrm{p}\left[\mathrm{Ca}^{2+}\right]+\mathrm{p}\left[\mathrm{HCO}_{3}^{-}\right]+5 \mathrm{pf}_{\mathrm{m}}
$$

The LSI and RI values were calculated as described in APHA et al. (2017), Shaha (2016) and Shaha et al. (2019). The water stability characteristics are interpreted as follows:

- If LSI $>0$, liquid is supersaturated and tends to precipitate scale.

- If LSI $=0$, liquid is neutral and is saturated (in equilibrium) with $\mathrm{CaCO}_{3}$. In other words, a scale layer of $\mathrm{CaCO}_{3}$ is neither precipitated nor dissolved. LSI values between -0.4 and +0.4 are considered to be neutral (Prisyazhniuk, 2007).

- If LSI $<0$, liquid is undersaturated and tends to dissolve solid $\mathrm{CaCO}_{3}$ as it is aggressive or corrosive in nature (Ozair, 2012).

Ryzner defined a "Stability Index” in 1944 (Ryzner, 1944; Montgomery, 1985) as follows:

$$
\mathrm{RI}=2 \mathrm{pH}_{\mathrm{s}}-\mathrm{pH}
$$

where, $\mathrm{pH}_{\mathrm{s}}$ is saturation $\mathrm{pH}$. RI values between 6.5 and 7.0 are considered to be approximately at saturation equilibrium with $\mathrm{CaCO}_{3}$. RI values $>7.0$ are interpreted as undersaturated, whereas RI values $<6.5$ are saturated and, hence, would tend to be scale-forming (Frederick, 1990). However, Müller-Steinhagen \& Branch (1988) observed that for higher concentrations of calcium and higher surface temperatures, RI predicts scaling for $\mathrm{CaCO}_{3}$ concentration well below the saturation concentration and thus should always be checked against LSI.

\subsubsection{X-Ray Diffraction Analysis}

Solid samples were dried in an oven at $105^{\circ} \mathrm{C}$ overnight and stored in a desiccator at room temperature. Then the samples were pulverized into fine powder using a mortar and pestle prior to analysis by BTX II Benchtop XRD unit. The analytical conditions were: cobalt X-rays with $\lambda=1.7903 \AA$ and a range of $2 \theta$ between $5^{\circ}-55^{\circ}$ to generate a diffraction pattern (intensity versus $2 \theta^{\circ}$ ). The Rietveld analysis technique (Young, 1993) was used for identification of unknown phases present in the solid samples. Phase identification (MATCH!, 2018) was achieved through search match calculations and Rietveld refinement using MATCH! 3.2.0 and FullProf, respectively. Bragg's coefficient (R) was used to measure agreement between the crystallographic model and the experimental XRD pattern. Although there are no threshold ranges for $\mathrm{R}$, lower R-values represent a better agreement between the calculated pattern and the pattern obtained from XRD. The minimum possible value of $\mathrm{R}$ is zero, indicating perfect agreement between experimental observations and the model (Brünger, 1992).

\subsection{Microbiological Analysis}

Metagenomic DNA from microbial communities of each sample was harvested by centrifugation and ultrafiltration and then sequenced via whole genome shotgun sequencing protocols to provide an accurate identification as well as functional capability of microbial communities (Leddy et al., 2017). In shotgun 
sequencing, random fragments of carefully prepared genomic libraries are sequenced with overlapping ends; which are then aligned into whole genomic reads using a rapid identification platform to detect and quantify all microbes including bacteria, archaea, viruses, fungi and protozoa in any sample in one step (Venter et al., 2004). In this analysis, the number of genomic reads is the number of genomes successfully assembled from the fragments sequenced. If this number is below $\sim 20$ million, then there is a chance that some important microorganisms were left out.

After transport to the laboratory, the biofilm samples were centrifuged and pelleted prior to DNA extraction. First, $10 \mathrm{~mL}$ of sample was aseptically pipetted into two sterile $5 \mathrm{~mL}$ test tubes and covered with parafilm. Then the test tubes were centrifuged at $3500 \mathrm{rpm}$ for 10 minutes to ensure all biofilm particles were pelleted. Next, $1000 \mathrm{~mL}$ sample blank was filtered through a $0.2 \mu \mathrm{m}$ membrane for each depth range and approximately $0.01 \mathrm{~g}$ pellet was obtained. Afterwards, the supernatant was decanted, and the pellets were kept at $4^{\circ} \mathrm{C}$ until DNA extraction. A final centrifugation at 14,000 rpm for 10 minutes of the pellet and residual supernatant was carried out prior to DNA extraction. The DNeasy PowerBiofilm ${ }^{\circledR}$ kit (MOBIO Laboratories, Inc., CA-USA) was used to extract DNA from the biofilm samples and the blanks using a combination of pre-treatment, chemical and mechanical lysis steps. This method is optimized to remove polymerase chain reaction (PCR) inhibitors such as heavy metals, salts and pesticides.

Approximately $0.1 \mathrm{~g}$ of pellet from each duplicate sample was weighed after centrifugation and applied to the kit. All pelleted samples were added separately to the PowerBiofilm ${ }^{\circledR}$ Bead Tubes then heated to activate lysis components that help to dissolve polysaccharides. Lysis continues through vortex mixing followed by protein and inhibitor removal with precipitation of humic substances as well as polyphenolics and polysaccharides. Total genomic DNA was captured on the MOBIO Laboratories flat bottom silica spin column where DNA is then washed and eluted from the spin column membrane for use in downstream PCR and sequencing reactions.

A Nanodrop 2000c spectrophotometer (Thermo Fisher Scientific, DE-USA) was used to measure the concentration and purity of the extracted DNA for each sample. DNA from the samples was further validated using gel electrophoresis prepared using a $1 \mathrm{X}$ TAE gel which ran for 40 minutes at $120 \mathrm{~V}$. The DNA was stained with the SYBR safe DNA gel stain (Thermo Fisher Scientific, DE-USA) and visualized using a UV transilluminator. After validation, the biofilm samples were pooled 1:1 prior to sequencing.

The extracted DNA samples and duplicates for each depth sample were combined before metagenomic shotgun sequencing and coded as: D1 (surface zone), D2 and a duplicate D2* (intermediate zone), D3 (deep zone). Prepared metagenomic DNA was then sent to a commercial sequencing platform (COSMOSID Inc., MD-USA) to carry out metagenomic shotgun sequencing. Sequencing primers targeted a wide range of bacteria, archaea, fungi, viruses, protozoan para- 
sites and also included virulence factors and antibiotic resistance genes. All sequences obtained were quality filtered and subsequently aligned and classified using the following GenBook ${ }^{\circledR}$ and NCBI databases and curated COSMOSID databases:

1) GenBook ${ }^{\circledR}$ Bacteria Database (31,064 genomes: 1579 genera and 4999 species) (R\&D);

2) GenBook ${ }^{\circledR}$ Virus Database (4352 Viral and bacteriophage genomes);

3) GenBooK $^{\circledR}$ Bacterial AR/VF Database (2638 Antibiotic Resistance and 2458 Virulence associated genes);

4) GenBook ${ }^{\circledR}$ Fungi Database (1024 genomes: 289 genera, 512 species);

5) GenBook ${ }^{\circledR}$ Protist Database (283 genomes: 72 genera, 184 species).

Here the term strain is meant to convey the natural concept of strain, and not necessarily its taxonomic meaning. That is, the assumption is that a strain in the database will always have a like counterpart in nature and potentially is a sub-sample derived from a strain found in nature. Relative abundance is calculated based on the number of organism specific kmers and their observed frequency in the sample and then normalized to represent the abundance of each organism. For each classification (protozoa, bacteria, viruses, etc.), a Chao 1 diversity index, which is a non-parametric estimation of the number of species present in a sample, was calculated. This parameter is used to measure the diversity of a sample, considering species presence and the number of times that species occurs. The equation for measuring the Chao 1 index is the total number of species in the sample added to the result of the number of singletons (number of species occurring only once in the sample) squared, divided by twice the number of doubletons (number of species occurring twice in the sample). The result of this equation is the Chao 1 diversity index.

\section{Results and Discussion}

\subsection{Water Quality Analyses}

The water quality field parameters $\mathrm{pH}$, specific conductance, conductivity, total dissolved solids, water temperature, dissolved oxygen, oxygen reduction potential (ORP), and turbidity, and analyzed each sample and the duplicates for the following water quality parameters in the laboratory: calcium, alkalinity, TDS, and chloride to estimate $\mathrm{CaCO}_{3}$ precipitation potential. A summary of the water quality parameters (field and laboratory) measured for water samples from each depth is found in Table 1.

Dissolved oxygen measurements were indicative of an anaerobic (reducing) environment, which was also supported by the negative ORP measurements. The $\mathrm{pH}$ observed from the intermediate zone (D2) and also the deep zone (D3) was 7.10, which matches with historical $\mathrm{pH}$ reported from similar composite leachate collected from this injection wet well in previous work (Shaha et al., 2019; Shaha, 2016; Townsend et al., 2016). However, $\mathrm{pH}$ observed for the surface zone sample (D1) was 7.98 and was slightly higher than expected. It is likely that 
Table 1. Summary of water quality analyses and estimated saturation indices (LSI and RI) at each depth.

\begin{tabular}{|c|c|c|c|c|c|}
\hline \multirow[b]{2}{*}{ Description } & \multirow{2}{*}{$\begin{array}{l}\text { Water Quality } \\
\text { Parameters }\end{array}$} & \multirow[b]{2}{*}{ Unit } & \multicolumn{3}{|c|}{ Sample } \\
\hline & & & $\begin{array}{c}D 1 \\
(0-61 \mathrm{~m})\end{array}$ & $\begin{array}{c}\mathrm{D} 2 \\
(62-457 \mathrm{~m})\end{array}$ & $\begin{array}{c}\text { D3 } \\
(458-884 \mathrm{~m})\end{array}$ \\
\hline \multirow{9}{*}{$\begin{array}{c}\text { Field } \\
\text { Parameters }\end{array}$} & $\mathrm{pH}$ & Standard Unit & 7.98 & 7.10 & 7.10 \\
\hline & Sp. Conductance & $\mathrm{mS} / \mathrm{cm}$ & 0.6 & 9.8 & 18.8 \\
\hline & Conductivity & $\mathrm{mS} / \mathrm{cm}$ & 0.6 & 9.9 & 20.2 \\
\hline & TDS (Field) & $\mathrm{mg} / \mathrm{L}$ & 350 & 6,340 & 12,210 \\
\hline & Water Temperature & ${ }^{\circ} \mathrm{C}$ & 25.8 & 26.0 & 28.9 \\
\hline & Turbidity & NTU & 113 & 169 & 162 \\
\hline & Dissolved Oxygen & $\mathrm{mg} / \mathrm{L}$ & 2.2 & $<1.0$ & $<1.0$ \\
\hline & ORP & $\mathrm{mV}$ & -38 & -404 & -415 \\
\hline & TDS (Gravimetric) & $\mathrm{mg} / \mathrm{L}$ & 390 & 5700 & 11,930 \\
\hline \multirow{3}{*}{$\begin{array}{l}\text { Laboratory } \\
\text { Parameters }{ }^{*}\end{array}$} & Calcium $(\mathrm{Ca})$ & $\mathrm{mg} / \mathrm{L}$ as $\mathrm{CaCO}_{3}$ & 250 & 1125 & 1600 \\
\hline & Alkalinity & $\mathrm{mg} / \mathrm{L}$ as $\mathrm{CaCO}_{3}$ & 150 & 2175 & 2125 \\
\hline & Chloride $\left(\mathrm{Cl}^{-}\right)$ & $\mathrm{mg} / \mathrm{L}$ & 350 & 2375 & 5575 \\
\hline \multirow{3}{*}{$\begin{array}{l}\text { Saturation } \\
\text { Indices }\end{array}$} & $\mathrm{pH}_{\mathrm{s}}$ & Standard Unit & 7.2 & 5.8 & 5.7 \\
\hline & LSI & Unitless & 0.8 & 1.4 & 1.4 \\
\hline & RI & Unitless & 6.4 & 4.4 & 4.3 \\
\hline
\end{tabular}

*All field parameters presented are the average of three readings recorded during sampling. ${ }^{*}$ All laboratory parameters presented are the average of the sample and the duplicate collected at each depth range.

this reading was caused by exposure to air or carbon dioxide degasification, as seen in prior work (Shaha et al., 2019; Shaha, 2016) in which pH spikes of up to 1.0-unit were observed in leachates depending on the alkalinity. Briefly, the lower the alkalinity, the more rapidly the $\mathrm{pH}$ climbs with exposure to air and subsequent degasification of carbon dioxide. From previous monitoring conducted by the researchers (Shaha et al., 2019; Shaha, 2016; Townsend et al., 2016), wet well sampling averaged $1200 \mathrm{mg} / \mathrm{L}$ as $\mathrm{CaCO}_{3}$ for alkalinity, but for the D1 sample, the alkalinity was measured at only $150 \mathrm{mg} / \mathrm{L}$ as $\mathrm{CaCO}_{3}$. Saturation carbon dioxide concentrations are proportional to pressure. Therefore, as soon as the pressure changes, so do the available carbon dioxide and subsequently the $\mathrm{pH}$.

The water temperature reading recorded above the injection zone (D3) was $28.9^{\circ} \mathrm{C}$, which was about 3 degrees higher than the other two samples. This is expected since the temperature increases with depth in the subsurface such that the water temperature at the borehole depth (610 - $915 \mathrm{~m}$ below surface) of the well is expected to be between $80-90^{\circ} \mathrm{F}\left(26^{\circ} \mathrm{C}-32^{\circ} \mathrm{C}\right.$ ) (Loeb \& Poupon, 1965; McKinley \& Thornhill, 1994). The temperature within the injection well is largely dependent on the temperature of the injectate that has displaced the native groundwater in the injection zone. The original temperature of the native groundwater prior to injection was about $60^{\circ} \mathrm{F}\left(15^{\circ} \mathrm{C}-16^{\circ} \mathrm{C}\right)$, which indicated 
some hydraulic connection with the ocean. So the general geothermal gradient of increased temperature with depth is only appropriate above the injection zone.

The surface zone sample (D1) showed low TDS (390 mg/L), alkalinity (150 $\mathrm{mg} / \mathrm{L}$ as $\mathrm{CaCO}_{3}$ ), and calcium $\left(250 \mathrm{mg} / \mathrm{L}\right.$ as $\left.\mathrm{CaCO}_{3}\right)$. In 2017-2018, the average TDS, alkalinity, and calcium in the deep injection wet well samples were found to be $6200 \mathrm{mg} / \mathrm{L}, 1200 \mathrm{mg} / \mathrm{L}$ as $\mathrm{CaCO}_{3}$, and $1100 \mathrm{mg} / \mathrm{L}$ as $\mathrm{CaCO}_{3}$, respectively. This nearly 10 -fold dilution may have been a signal of stratification in the injection tubing. Stratification occurs because higher salinity water is denser and sinks to the bottom, while lower salinity water is less dense and tends to rise to the surface. The shallow zone data may also reflect that the injection well was flushed with a volume of potable water previously to conduct a video survey. However, this should not have any adverse impact on the mineralogical analysis of the solid samples collected and analyzed by XRD.

The gravimetric solids analysis (TDS) performed in the laboratory matched the field TDS obtained using the YSI 556 multiparameter meter within relative error less than $10 \%$. All other data obtained from the samples collected from the intermediate zone (D2) and from above the injection zone (D3) were within the expected ranges, and QA/QC samples were less than $3 \%$ error for alkalinity, calcium, and chloride. LSI in the intermediate zone and above the injection zone was 1.4, which indicates supersaturation with respect to $\mathrm{CaCO}_{3}$. RI values at the same depths were 4.3 - 4.4, indicating the scale-forming nature of the samples.

\subsection{Solids Composition}

A summary of the XRD analysis and Rietveld refinement using MATCH! 3.02 is presented in Table 2 and Figure 2.

For comparison purposes, a pure calcite $\left(\mathrm{CaCO}_{3}\right)$ sample was analyzed using XRD. The search match calculation and Rietveld refinement confirmed the composition to be $100 \%$ calcite. For the three depths, x-ray diffraction (XRD)

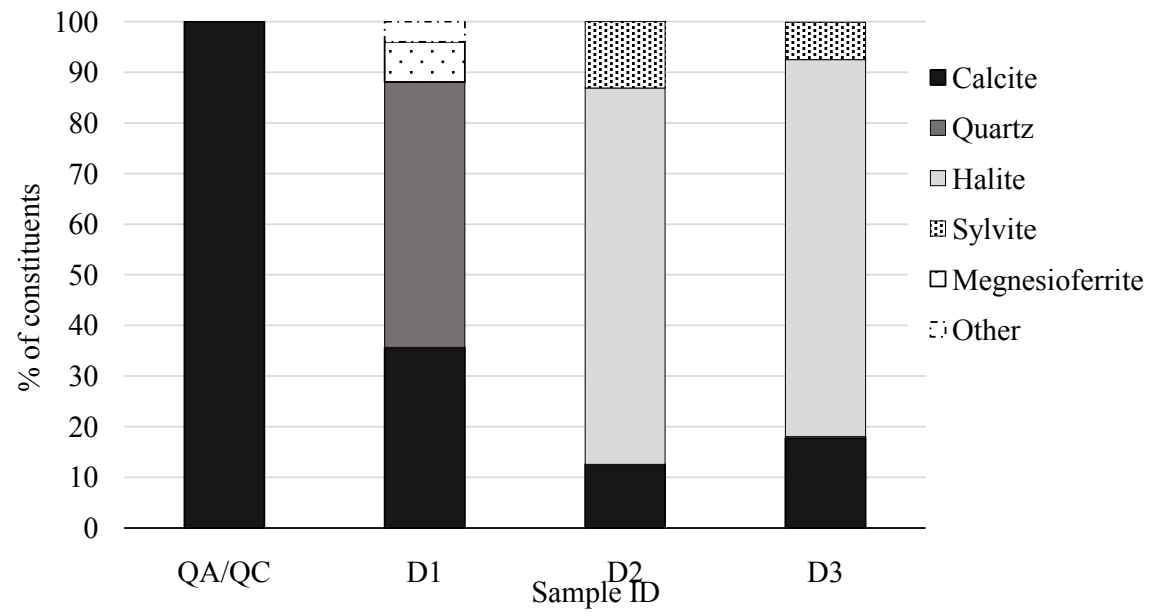

Figure 2. Stacked bar chart showing the composition of the samples at each depth compared to a pure calcite QA/QC standard. 
Table 2. Summary of XRD pattern analysis and Rietveld refinement using MATCH! 3.02.

\begin{tabular}{cc}
\hline Sample ID & $\begin{array}{c}\text { Composition Based on XRD Diffraction } \\
\text { Pattern and Rietveld Refinement }\end{array}$ \\
\hline QA/QC (Pure Calcite) & Calcite-100\% (Figure 2) \\
D1 & Quartz- $52.4 \%$ \\
"Surface Zone" & Calcite- $35.7 \%$ \\
$(0-61 \mathrm{~m})$ & Magnesioferrite-7.9\% \\
& Other-4.0\% \\
D2 & Halite- $74.3 \%$ \\
"Intermediate Zone" & Sylvite-13.1\% \\
$(62-457 \mathrm{~m})$ & Magnesium Calcite-12.6\% \\
& Halite- $74.4 \%$ \\
D3 & Calcite- $17.8 \%$ \\
"Deep Zone" & Sylvite- $7.4 \%$ \\
& Quartz-0.3\% \\
\hline
\end{tabular}

confirms that calcite was present. In addition, the presence of salts (halite- $\mathrm{NaCl}$ and sylvite- $\mathrm{KCl}$ ) in the matrix increased with depth as the salinity increased. In the solids collected from the surface zone sample (D1), an amount of quartz $\left(\mathrm{SiO}_{2}\right)$ was also identified. This was expected because $\mathrm{SiO}_{2}$ is typically found in sand, which is a common material found in wastewater collection systems. Magnesioferrite $\left[\mathrm{Mg}\left(\mathrm{Fe}^{3+}\right)_{2} \mathrm{O}_{4}\right]$ was also present in the $\mathrm{D} 1$ sample. This too was expected because of the availability of the dissolved oxygen and also magnesium and iron are common cations in the injectate. The unidentified "other" material indicated in the D1 sample was likely an artifact of Rietveld refinement. Preliminary attempts using halite $(\mathrm{NaCl})$ and other common salts did not converge. Therefore, the "other" material represents unidentifiable contaminants in the sample that were not found in the database used in this analysis.

\subsection{Microbiological Analysis of Biofilm}

The first step of microbiological analysis is the preparation of pure DNA in a defined state since other macromolecules (RNA and proteins) can interfere with the accurate quantitation. The purity of DNA preparation was monitored spectrophotometrically by measuring the absorbance at $260 \mathrm{~nm}$ relative to $280 \mathrm{~nm}$ $\left(\mathrm{A}_{260} / \mathrm{A}_{280}\right)$ and presented in Table 3. In general, a $\mathrm{A}_{260} / \mathrm{A}_{280}$ ratio between 1.8 and 2.0 is considered to be a pure preparation of DNA. Five of the six prepared DNA samples fell within the range, which confirms the integrity of prepared DNA. The sample obtained from intermediate zone (D2) showed a $A_{260} / A_{280}$ ratio of 2.1, indicative of hyperchromaticity; which may have resulted from the presence of RNA or DNA denaturation. The $\mathrm{A}_{260} / \mathrm{A}_{280}$ ratios for the blank (Q1, Q2, and Q3) samples were below-threshold, and indicate the absence of DNA, protein, phenols or other contaminants that absorb strongly at or near $280 \mathrm{~nm}$.

One genomic read is the cumulative sequence read after de novo assembly of contigs. It is not the same as total counts because some organisms have more than one chromosome. However, most bacteria have one chromosome. So, this 
Table 3. DNA Concentration from Nanodrop Measurements.

\begin{tabular}{ccc}
\hline Sample Description/Source & $\begin{array}{c}\text { Concentration } \\
(\mathrm{ng} / \mu \mathrm{L})\end{array}$ & $\begin{array}{c}\text { Purity } \\
\mathrm{A}_{260} / \mathrm{A}_{280}\end{array}$ \\
\hline D1 $(\mathbf{0}-\mathbf{6 1 \mathrm { m } )}$ & 21.3 & 2.0 \\
D1*(0-61 m) & 19.1 & 2.0 \\
D2 $(62-\mathbf{4 5 7} \mathrm{m})$ & 17.7 & 2.1 \\
D2* $(62-\mathbf{4 5 7} \mathrm{m})$ & 30.8 & 2.0 \\
D3 $(\mathbf{4 5 8}-\mathbf{8 8 4} \mathrm{m})$ & 14.3 & 1.9 \\
D3* (458 - 884 m) & 31.0 & 1.9 \\
Q1, Elevation Blank & 4.8 & 1.2 \\
Q2, Elevation Blank & 3.7 & 1.2 \\
Q3, Elevation Blank & 2.6 & 1.3 \\
\hline
\end{tabular}

Note: *sample duplicate; $\mathrm{Q}_{\mathrm{i}}$ represents blank at $\mathrm{i}^{\text {th }}$ depth interval.

number is a good reflection of the sequencing coverage. The higher the number of organisms (using the same depth of coverage), the higher the total reads will be. In this case, each sample had a higher number of reads, which averaged close to 75 million (Figure 3). This was indicative of successful assemblage. As stated earlier, if the number of reads is below $\sim 20$ million for a niche like this, then there is a chance that some important microorganisms were missed. In these samples however, over 70 million genomic reads were obtained, providing sufficient span to capture most representative members of the microbiota in the injection well.

In terms of microbiological composition, there was no algae found in any of the samples as expected, since no photosynthetic light sources are available inside the injection well. The Chao 1 diversity index represents the predicted number of taxa from each major kingdom. The virus and protist indices remained approximately the same for each sample. As shown in Table 4, the Chao 1 diversity indices for bacteria, viruses and protozoans were highest at 0-61 m and gradually declined with increasing depth. A combination of factors, including nutrient availability, obligate anaerobiosis (microbes that require the absence of oxygen to proliferate) and pressure to a lesser extent can explain this. Increasing depth typically means less available electron acceptors and readily biodegradable nutrients, which favors the richness of only a few specialized microbes.

The protozoan taxa abundance is summarized in Figure 4. Entamoeba dispar, a non-pathogenic protozoan similar to the pathogenic Entamoeba histolytica, was the most prevalent protozoan found in the samples ( 35\%), while the ciliate Stylonchia lemnae increased in abundance as the depth increased (8\% - 13\%). Of particular interest is the dynamics of the bacteria-eating amoeba (also called slime molds) of the Dictyostelium spp. The abundance of these biofilm generating amoebas peaked at the middle elevation tested in the well. These organisms 
Table 4. Summary of the Chao 1 diversity index obtained for bacteria, protozoa and viruses by sample depth.

\begin{tabular}{ccccc}
\hline \multicolumn{5}{c}{ Sample Source/Depth (m) } \\
\hline Organisms & D1 (0 - 61) & D2 (62 - 457) & D2* (62 - 457) & D3 (457 - 884) \\
\hline Bacteria & 228 & 201 & 194 & 185 \\
Viruses & 37 & 30 & 30 & 26 \\
Protists & 2 & 1 & 0 & 0 \\
\hline
\end{tabular}

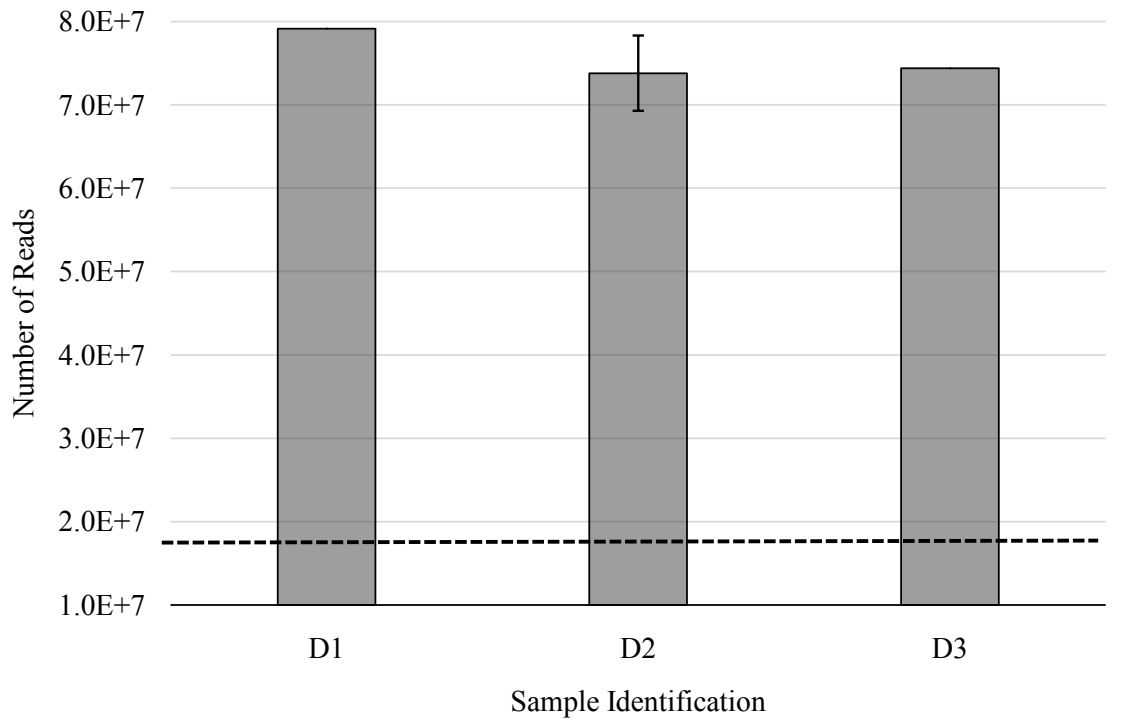

Figure 3. Bar plot showing the total number of reads obtained post-quality filtering. Note dotted line signifies the minimum number of reads for completeness, and error bars denote one standard deviation about the mean.

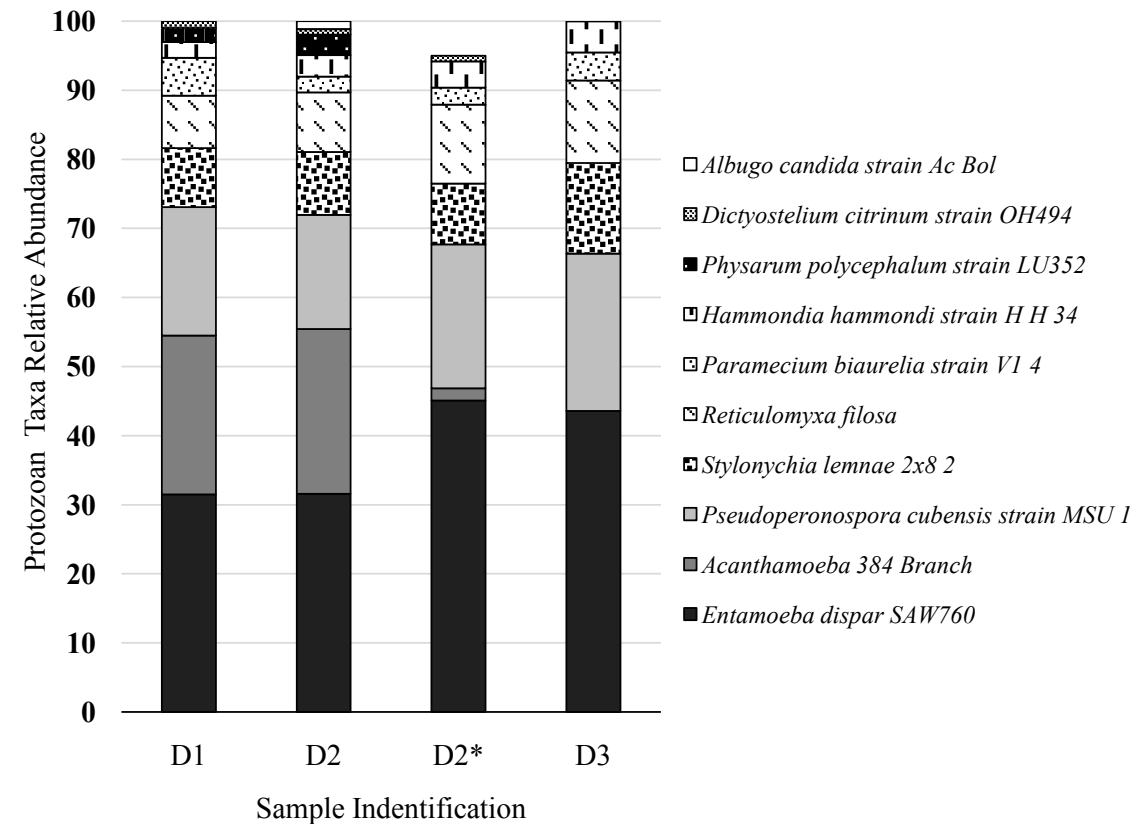

Figure 4. Stacked bar charts showing the relative abundance of the protozoan taxa down to the strain level. 
are known to aggregate as nutrient availability decreases, (presumably at the 61 $457 \mathrm{~m}$ depth in this case); to form profuse biofilm structures with well-organized behavior.

A summary of the 10 most abundant bacterial taxa identified is found in Figure 5. Methanosaeta concilli, an anaerobic mesophilic methanogen was the most prevalent species in all the samples $(\sim 30 \%)$ except for samples taken from above the injection zone $(\sim 23 \%)$. The two most dominant species observed were the methanogenic archaea (Methanosarcina and Methanosaeta) and sulfate-reducing bacteria (Desulfobulbus and Desulfococcus $\sim 14 \%$ ), which are prokaryotic anaerobic biofilm producers. There was a gradual increase for the methanogens Methanosarcina spp. as the depths increased, while the sulfate-reducing bacteria remained consistent. Early studies have implicated methanogenic archaea and sulfate-reducing bacteria in the formation of anaerobic biofilms (Yoda et al., 1987; Amann et al., 1992). In this study, many of these organisms were most prevalent in the deep injection well system where they normally out-compete each other based on available sulfate and acetate. Methanosaeta concilli and Methanosarcina spp. which were found most prevalent in all samples uses acetate to form methane and has also been shown to be associated with biofilms (Ganzert et al., 2014). Methanosaeta concilli is known to immobilize and form large clumps when acetate concentrations are elevated (Schmidt \& Ahring, 1999). Another methanogen, Methanosarcina spp., showed relative abundance gradually increasing with increasing depth. Sulfate-reducing bacteria such as Desulfococcus multivorans are commonly observed in developing and established multispecies biofilms (Amann et al., 1992). The Desulfococcus bacteria had the lowest relative abundance in the middle elevation of the injection well.

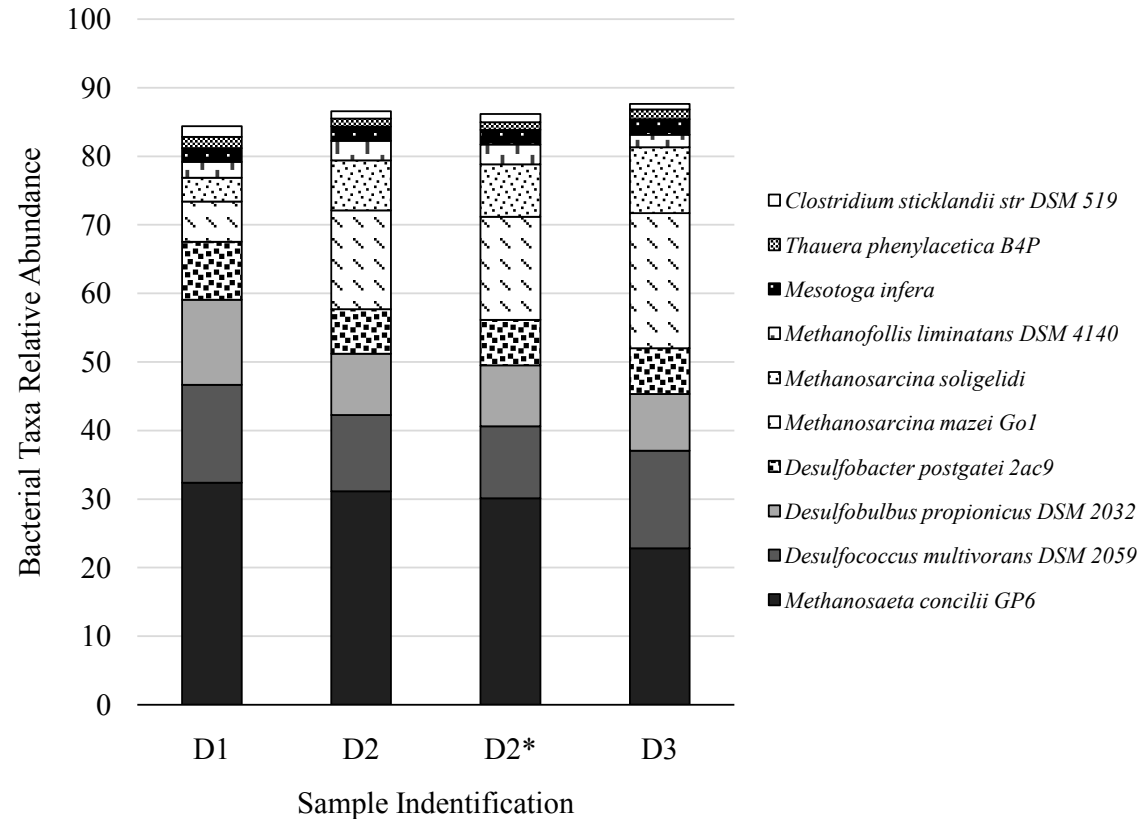

Figure 5. Stacked bar charts showing the relative abundance of the top 10 bacterial taxa down to the strain level. 
However, one of the most common biofilm colonizers, Pseudomonas aeruginosa was found at relatively low abundance.

In Figure 6, a heatmap of viral taxa relative abundance is shown. Pseudomonas phage was the most prevalent virus found throughout the samples. Pseudomonas phage Kakheti is a broad-spectrum phage and its presence is likely the reason for the low relative abundance $(<0.3 \%)$ of Pseudomonas aeruginosa (a very common biofilm colonizer) and other Pseudomonas spp. that were expected but not found in high numbers in the different samples.

In addition, the antibiotic resistance gene pool diversity is highest in the surface zone sample and decreases with increasing depth. The decline is evident but there is still an important quantity of antibiotic resistant genes still intact above the injection zone. Predation and degradation may account for some clearing of the resistance genes.

\section{Conclusions and Recommendations}

To investigate the mineral content of solid samples collected from three depths from the industrial deep injection well, water quality and $\mathrm{x}$-ray diffraction tests were conducted. The water quality parameters indicate scale forming potential, and $\mathrm{x}$-ray diffraction confirms the composition of the solids collected was mostly calcium carbonate $\left(\mathrm{CaCO}_{3}\right)$ with contributions from salts such as sodium chloride $(\mathrm{NaCl})$ and potassium chloride $(\mathrm{KCl})$. In terms of microbiological composition, there was no algae found in any of the samples as expected, since no photosynthetic light sources are available inside the injection well. The Chao alpha

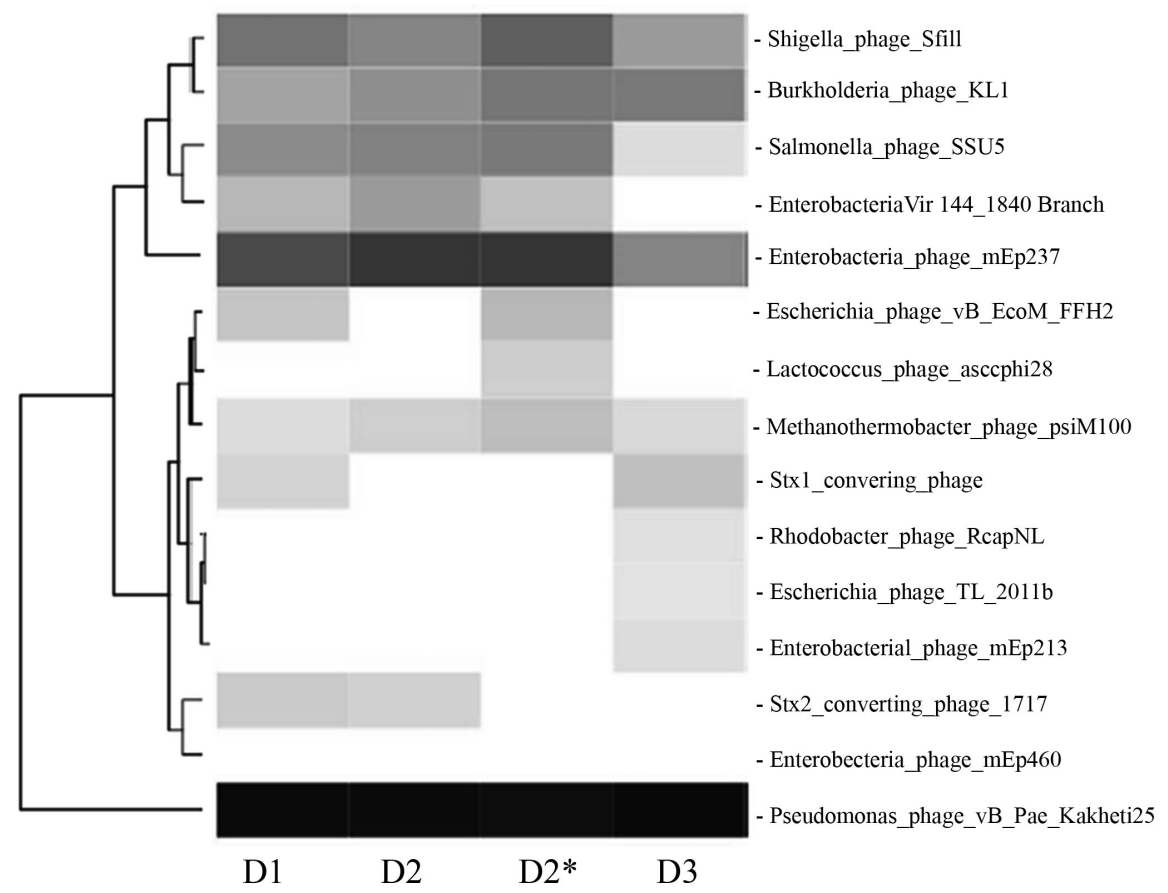

Figure 6. Heatmap showing the relative abundance of the different viral taxa from each sample (Note: higher abundance is denoted by darker colors). 
diversity indices for bacteria, viruses and protozoans were highest at 0-61 $\mathrm{m}$ and gradually declined with increasing depth. A combination of factors, including nutrient availability, obligate anaerobiosis (microbes that require the absence of oxygen to proliferate) and pressure to a lesser extent can explain this. Increasing depth typically means less available electron acceptors and readily biodegradable nutrients, which favors the richness of only a few specialized microbes. The prevalent species at D3 are not barophilic organisms that thrive at high pressures, rather they are sulfate reducing bacteria involved in anaerobic dissimilatory sulfate metabolism. Methanogenic archaea and sulfate-reducing bacteria both of which are anaerobic biofilm producers were the most prevalent members of the prokaryotic community at all depths. Methanosarcinae spp. increased with increasing depths unlike other archaea. A non-pathogenic biofilm-producing Entoamoeba dispar was the most prevalent member of the microbial domain $(>30 \%)$ in all samples.

When a biofouling problem has begun, little can be done to remove it permanently expect for replacing the tubing completely. To avoid replacement, control of the colonies is the preferred strategy. Options for management of biofouling on deep injection well tubing include pre-treatment of the injectate and/or tailored well rehabilitation strategies.

\subsection{Pre-Treatment}

Pre-treatment can take the form of aeration, acidification and/or disinfection prior to injection. Sulfate-reducers and methanogens are anaerobic, which means that they cannot maintain themselves in a medium in which oxygen is present periodically (van Beek, 1984). Therefore, in theory, introducing aeration in periodic pulses in the wet well could potentially help to control these microorganisms, but currently there is some degree of aeration that is occurring in the wet well by virtue of how the different waters are brought to the well (and this does not seem to be controlling the anaerobic bacterial populations). Adding air could enhance the growth rate of aerobic biofilm colonizers too. Further, work (Shaha et al. 2019; Shaha et al. 2016; Shaha 2016; Townsend et al., 2016) showed that aeration tends to increase the $\mathrm{pH}$ by nearly one full unit, which would have the unintended consequence of stimulating calcium carbonate mineral scale deposits. This leaves disinfection as an option. AWWA (2014) recommends chlorinating water prior to groundwater injection.

\subsection{Well Rehabilitation}

Well rehabilitation efforts must be tailored to and designed around the site-specific characteristics and chemistry of the receiving water and the injectate and be compatible with the construction and use patterns of the injection well. Chemical options and restoration procedures should be based on: safety considerations, well construction, aquifer conditions, local availability, past experience, degree of success, cost, peer recommendations, and the background groundwa- 
ter quality (Butts, 2017). Chlorine and various acids, surfactants, and dispersants have been used for decades, often with mixed success due to the uncertainty of solution strength, mixture uniformity/distribution, and penetration. It should be noted that fouling due to mineral encrustation alone is relatively rare when not accompanied by some form of biofilm growth, requiring the use of a biocide like chlorine.

One well rehabilitation strategy could include administering acid during mechanical brushing. Acid will lower the $\mathrm{pH}$ to dissolve target chemical precipitates like calcites. Using inorganic acids such as high strength hydrochloric acid is preferred over organic acids such as acetic or citric acids because of the potential for rapid microbial regrowth as a source of food. Another technique would be to use chemical oxidizers such as hydrogen peroxide (Brassington et al., 2009) or sodium hypochlorite (or other forms of chlorination) to target organic matter or microorganisms, but peroxide adds a source of oxygen, which can trigger regrowth of iron bacteria. Nitric acid combines the effect of an acid with an oxidizer but adds nutrients in the form of nitrate to the matrix. If the issue is focused on the open hole rather than the well tubing, then a mixture of $30 \mathrm{~L}$ (7.9 gal) of hydrogen peroxide (35\%) and $1 \mathrm{~L}(0.26 \mathrm{gal})$ of hydrochloric acid into every meter (3.3 ft) of the hole (Timmer et al., 2003) has been used successfully in the Netherlands and in conjunction with enlarging the well diameter. This technique may not address issues localized to the injection tubing.

Another method developed in Alaska (Butts, 2017) involves heating a chlorine solution and injecting it into the well. In this method, $65 \%-70 \%$ strength of dry calcium hypochlorite is mixed with preheated water developed from a steam cleaner to create a chlorine solution of about $500 \mathrm{mg} / \mathrm{L}$ strength at $75^{\circ} \mathrm{C}-85^{\circ} \mathrm{C}$ $\left(170-180^{\circ} \mathrm{F}\right)$. The solution is vigorously mixed in the drum while the tablets are slowly introduced and mixed with the hot water. Upon complete mixing, the solution is then introduced for a contact time of at least 6 hours along with periodic agitation before diluting and pumping the solution out of the well. The process may have to be repeated several times and concentrated in the specific region with the thickest encrustation for best results (Butts, 2017). However, the extra calcium in the chlorine tablets could cause unintended increases of mineral scale precipitation if not removed from the well tubing completely.

The City of Venice, FL experienced biofouling problems in their raw water extraction wellfield attributed to Pseudomonas. In response, the City instituted a routine disinfection program of 3 well volumes of $6000 \mathrm{mg} / \mathrm{L}$ chlorine for a contact time of at least 6 - 24 hours with periodic agitation, on a monthly basis. Initially, the process was repeated multiple times and concentrated in the specific elevation where the thickest biofilm was recorded. Once the biofilm was under control, the time between disinfection events was extended to 90 days (AWWA, 2014). The City of Hollywood and the Collier County Water/Sewer District have also adopted this protocol for their water supply wells to reduce the potential for fouling membrane plants. However, while this procedure was not developed for deep injection wells specifically, there is no reason to expect that it would not be 
successful in practice, and the disposal of the concentrated solution is not an issue. The high concentration should stay in the borehole and casing for 48 hours. Although free chlorine is reported to have limited penetration into biofilm matrices (De Beer et al., 1994), it is still expected to provide a beneficial effect on biofilms. Other disinfection agents such as monochloramine are reportedly better able to penetrate and kill biofilm bacteria than free chlorine, and chloramines are longer lasting (LaChevallier et al., 1988). Since there is an appreciable amount of ammonia already present in the injectate $\left(\sim 200-400 \mathrm{mg} / \mathrm{L}\right.$ as $\left.\mathrm{NH}_{4}^{+}\right)$, some of the chlorine will react with ammonia to form combined chlorine (chloramines) in the well. Disinfection theory is based on disinfectant concentration (C) and contact time (T). The USEPA published guidance (Malcolm Pirnie, Inc. \& HDR Engineering, Inc., 1990) on the levels and effectiveness of disinfection agents using the CT parameter is based on enteric viruses and Giardia lamblia. This parameter is used by other references in literature (LaChevallier et al., 1988; Bridier et al., 2011) to determine appropriate disinfection conditions for cases involving biofilms, for example. A word of caution is that the local bioflora that is detailed in this study is comprised of a diverse microcosm including cyst-forming protozoa (Entamoeba dispar), pseudomonas phage (viruses that infect Pseudomonas), sulfate-reducers including filamentous types, and methanogenic archaea. These last two are slow-growing microorganisms that have competitive advantages for resources in anoxic conditions, and the protozoa may be grazing on certain vegetative bacteria, keeping their fast-growing populations in check. Therefore, any attempt to control the population of the current microcosm could bring about an imbalance that would favor the fast-growing microbes that may or may not be more problematic with respect to biofilm issues in the well.

\section{Acknowledgements}

The researchers would like to thank the Solid Waste Authority of Palm Beach County and AECOM/URS for funding this project.

\section{Conflicts of Interest}

The authors declare no conflicts of interest regarding the publication of this paper.

\section{References}

AECOM (2019). DIW Waste Stream Geochemical Modeling and DIW Microbial and Mineral Growth. West Palm Beach, FL.

Al-Rawajfeh, A. E., Glade, H., \& Ulrich, J. (2005). Scaling in Multiple-Effect Distillers: The Role of $\mathrm{CO}_{2}$ Release. Desalination, 182, 209-219.

https://doi.org/10.1016/j.desal.2005.04.013

Amann, R. I., Stromley, J., Devereux, R., Key, R., \& Stahl, D. A. (1992). Molecular and Microscopic Identification of Sulfate-Reducing Bacteria in Multispecies Biofilms. Applied and Environmental Microbiology, 58, 614-623.

APHA, AWWA, WEF (American Public Health Association, American Water Works 
Association, and Water Environment Federation) (2017). Standard Methods for the Examination of Water and Wastewater (23rd ed.).

AWWA (American Water Works Association) (2014). Groundwater Manual of Water Supply Practices. M21 (4th ed.).

Blenkinsopp, S. A., \& Costerton, J. W. (1991). Understanding Bacterial Biofilms. Trends in Biotechnology, 9, 138-143. https://doi.org/10.1016/0167-7799(91)90045-J

Bloetscher, F., Bullock, R. J., Fergen, R. E., Witt, G. M., \& Fries, G. D. (2002a). Revisiting the Selection of Stainless Steel Grades in Water and Wastewater Treatment Environments-Part 1. Water Engineering and Management, 149, 36-44.

Bloetscher, F., Bullock, R. J., Fergen, R. E., Witt, G. M., \& Fries, G. D. (2002b). Revisiting the Selection of Stainless Steel Grades in Water and Wastewater Treatment Environments-Part 2. Water Engineering and Management, 149, 12-15.

Bloetscher, F., Bullock, R. J., Fergen, R. E., Witt, G. M., \& Fries, G. D. (2002c). Revisiting the Selection of Stainless Steel Grades in Water and Wastewater Treatment Environments-Part 3. Water Engineering and Management, 149, 12-26.

Bloetscher, F., Meeroff, D. M., Pisani, J. V., \& Long, S. (2010). Resolving Biofilms in Buildings and Compounds. Journal of Environmental Engineering Science, 27, 767-776. https://doi.org/10.1089/ees.2009.0422

Boulding, J. R., \& Jones, A. C. (1990). Assessing the Geochemical Fate of Deep-Well-Injected Hazardous Waste: A Reference Guide (No. PB-91-145706/XAB). Arlington, MA: Eastern Research Group, Inc.

Brassington, F. C., Whitter, J. P., MacDonald, R. A., \& Dixon, J. (2009). The Potential Use of Hydrogen Peroxide in Water Well Rehabilitation. Water and Environment Journal, 23, 69-74. https://doi.org/10.1111/j.1747-6593.2008.00132.x

Bridier, A., Briandet, R., Thomas, V., \& Dubois-Brissonnet, F. (2011). Resistance of Bacterial Biofilms to Disinfectants: A Review. Biofouling, 27, 1017-1032. https://doi.org/10.1080/08927014.2011.626899

Brünger, A. T. (1992). Free R Value: A Novel Statistical Quantity for Assessing the Accuracy of Crystal Structures. Nature, 355, 472-475.

Butts, E. (2017). Part 4: Rehabilitation Techniques and Improving Efficiency in Wells. Water Well Journal.

De Beer, D., Srinivasan, R., \& Stewart, P. S. (1994). Direct Measurement of Chlorine Penetration into Biofilms during Disinfection. Applied and Environmental Microbiology, 60, 4339-4344.

De Moel, P. J., Van der Helm, A. W. C., Van Rijn, M., Van Dijk, J. C., \& Van der Meer, W. G. J. (2013). Assessment of Calculation Methods for Calcium Carbonate Saturation in Drinking Water for DIN 38404-10 Compliance. Drinking Water Engineering and Science, 6, 115-124. https://doi.org/10.5194/dwes-6-115-2013

FDEP (2017). Municipal Solid Waste Management Annual Report.

Fleming, I. R., Rowe, R. K., \& Cullimore, D. R. (1999). Field Observations of Clogging in a Landfill Leachate Collection System. Canadian Geotechnical Journal, 36, 685-707. https://doi.org/10.1139/t99-036

Frederick, W. P. (1990). Water Quality and Treatment-A Handbook of Community Water Supplies. New York: McGraw Hill Inc.

Ganzert, L., Schirmack, J., Alawi, M., Mangelsdorf, K., Sand, W., Hillebrand-Voiculescu, A., \& Wagner, D. (2014). Methanosarcina spelaei sp. nov., a Methanogenic Archaeon Isolated from a Floating Biofilm of a Subsurface Sulphurous Lake. International Journal of Systematic and Evolutionary Microbiology, 64, 3478-3484. 
https://doi.org/10.1099/ijs.0.064956-0

Hwang, C., Ling, F., Andersen, G. L., LaChevallier, M. W., \& Liu, W. T. (2012). Evaluation of Methods for the Extraction of DNA from Drinking Water Distribution System Biofilms. Microbes and Environments, 27, 9-18.

LaChevallier, M. W., Cawthon, C. D., \& Lee, R. G. (1988). Inactivation of Biofilm Bacteria. Applied and Environmental Microbiology, 54, 2492-2499.

Leddy, M. B., Hasan, N. A., Subramanian, P., Heberling, C., Cotruvo, J., \& Colwell, R. R. (2017). Characterization of Microbial Signatures from Advanced Treated Wastewater Biofilms. Journal: American Water Works Association, 109, E503-E512.

https://doi.org/10.5942/jawwa.2017.109.0116

Levine, A. D., Cardoso, A. J., Nayak, B., Rhea, L. R., Dodge, B. M., \& Harwood, V. J. (2005). Assessment of Biogeochemical Deposits in Landfill Leachate Drainage Systems. Final Report.

Loeb, J., \& Poupon, A. (1965). Temperature Logs in Production and Injection Wells. In 27th Meeting of the European Association of Exploration Geophysicists.

Luo, B., Zhao, X., Liang, B., \& Dong, G. (2009). Study on Water Quality Chemical Stability of Desalinated Seawater in Municipal Water Supply Systems. In 2009 International Conference on Environmental Science and Information Application Technology (Vol. 1, pp. 344-348). Wuhan. https://doi.org/10.1109/ESIAT.2009.242

Malcolm Pirnie, Inc., \& HDR Engineering, Inc. (1990). Guidance Manual for Compliance with Filtration and Disinfection Requirements for Public Water Supply Systems Using Surface Water Sources. Washington DC: Science and Technology Branch, USEPA.

Maliva, R. G., Missimer, T. M., Leo, K. C., Statom, R. A., Dupraz, C., Lynn, M., \& Dickson, J. A. D. (2000). Unusual Calcite Stromatolites and Pisoids from a Landfill Leachate Collection System. Geology, 28, 931-934. https://doi.org/10.1130/0091-7613(2000)28<931:UCSAPF >2.0.CO;2

MATCH! (2018). Version 3.x, CRYSTAL IMPACT, Kreuzherrenstr. Bonn, Germany. http://www.crystalimpact.com/match

Mayer, N. P., Hernandez, M. J., Mulla Saleh, A. R., Carl, S. S., \& Calistri, R. (2013). Biogeochemical Clogging of Landfill Leachate Collection Systems. Why Is It Occurring. How Can It Be Cleaned. What Can Be Done to Prevent It Part I. Waste Advantage.

Mayer, N. P., Hernandez, M. J., Mulla Saleh, A. R., Carl, S. S., \& Calistri, R. (2014). Biogeochemical Clogging of Landfill Leachate Collection Systems. Why Is It Occurring. How Can It Be Cleaned. What Can Be Done to Prevent It Part II. Waste Advantage.

McKinley, R. M., \& Thornhill, J. T. (1994). Temperature, Radioactive Tracer, and Noise Logging for Injection Well Integrity. Robert S. Kerr Environmental Research Laboratory, Office of Research and Development, US Environmental Protection Agency.

McLaughlan, R. (2002). Managing Water Well Deterioration: IAH International Contributions to Hydrogeology (Vol. 22).

Melcer, A., Gerrish, H. W., Apps, J. A., \& Tsang, C. (1996). Effects of Formation Damage on Injection Operations and on Pressure Transient Tests. In J. A. Apps, \& C. Tsang (Eds.), Deep Injection Disposal of Hazardous and Industrial Waste (pp. 277-286). San Diego, CA: Academic Press.

Montgomery, J. M. (1985). Water Treatment Principles \& Design (pp. 424). New York: John Wiley \& Sons.

Mulla Saleh, A. R. (2006). Assessment of Biogeochemical Deposits in Landfill Leachate Drainage Systems Phase II. Doctor of Philosophy, Tampa, FL: University of South Florida. 
Müller-Steinhagen, H. M., \& Branch, C. A. (1988). Comparison of Indices for the Scaling and Corrosion Tendency of Water. The Canadian Journal of Chemical Engineering, 66, 1005-1007. https://doi.org/10.1002/cjce.5450660617

Nia, M. G., Rahimi, H., Sohrabi, T., Naseri, A., \& Tofighi, H. (2010). Potential Risk of Calcium Carbonate Precipitation in Agricultural Drain Envelopes in Arid and Semi-Arid Areas. Agricultural Water Management, 97, 1602-1608. https://doi.org/10.1016/j.agwat.2010.05.014

Ochi, J., \& Vernoux, J. F. (1996). Origin of Permeability Reduction under High-Flow-Rate Injection Conditions. Deep Injection Disposal of Hazardous and Industrial Waste, 637-650.

Omar, W., Chen, J., \& Ulrich, J. (2010). Reduction of Seawater Scale Forming Potential Using the Fluidized Bed Crystallization Technology. Desalination, 250, 95-100. https://doi.org/10.1016/j.desal.2009.03.013

Ozair, G. (2012). An Overview of Calcium Carbonate Saturation Indices as a Criterion to Protect Desalinated Water Transmission Lines from Deterioration. Nature, Environment and Pollution Technology, 11, 203-212.

Prisyazhniuk, V. A. (2007). Prognosticating Scale-Forming Properties of Water. Applied Thermal Engineering, 27, 1637-1641.

https://doi.org/10.1016/j.applthermaleng.2005.12.004

Qasim, S. R., Motley, E. M., \& Zhu, G. (2000). Water Works Engineering: Planning, Design, and Operation. Upper Saddle River, NJ: Prentice Hall.

Ryzner, J. W. (1944). A New Index for Determining Amount of Calcium Carbonate Formed by a Water. Journal (American Water Works Association), 36, 472-483.

https://doi.org/10.1002/j.1551-8833.1944.tb20016.x

Saripalli, K. P., Sharma, M. M., \& Bryant, S. L. (2000). Modeling Injection Well Performance during Deep-Well Injection of Liquid Wastes. Journal of Hydrology, 227, 41-55. https://doi.org/10.1016/S0022-1694(99)00164-X

Schmidt, J. E., \& Ahring, B. K. (1999). Immobilization Patterns and Dynamics of AcetateUtilizing Methanogens Immobilized in Sterile Granular Sludge in Upflow Anaerobic Sludge Blanket Reactors. Applied and Environmental Microbiology, 65, 1050-1054.

Shaha, B. N. (2016). Effect of Electronic Water Treatment System on Calcium Carbonate Scaling. Boca Raton, FL: Florida Atlantic University. https://doi.org/10.1061/9780784479865.005

Shaha, B. N., Meeroff, D. E., \& Kohn, K. (2016). Effect of an Electronic Water Treatment System on Calcium Carbonate Scaling: A Case Study. World Environmental and Water Resources Congress 2016 (pp. 41-50). https://doi.org/10.1061/9780784479865.005

Shaha, B. N., Meeroff, D. E., Kohn, K., Townsend, T. G., Mayer, N., Schultz, R., \& Telson, J. (2019). Effect of Electronic Water Treatment System on Calcium Carbonate Scale Formation in Landfill Leachate Collection Piping. Journal of Environmental Engineering, 145, Article ID: 04019052. https://doi.org/10.1061/(ASCE)EE.1943-7870.0001567

Stow, S. H., \& Johnson, K. S. (1990). Chapter 7. Environmental Impacts Associated with Deep-Well Disposal. In P. E. LaMoreaux, \& J. Vrba (Eds.), Hydrogeology and Management of Hazardous Waste by Deep-Well Disposal (Vol. 12). London: International Association of Hydrogeologists.

Timmer, H., Verdel, J. D., \& Jongmans, A. G. (2003). Well Clogging by Particles in Dutch Well Fields. Journal (American Water Works Association), 95, 112-118. https://doi.org/10.1002/j.1551-8833.2003.tb10434.x 
Townsend, T., Meeroff, D. E., \& Schert, J. (2016). Critical Examination of Leachate Collection System Clogging at SWA Disposal Facilities. Final Report.

Van Beek, C. G. E. M. (1984). Restoring Well Yield in the Netherlands. Journal (American Water Works Association), 76, 66-72. https://doi.org/10.1002/j.1551-8833.1984.tb05422.x

VanGulck, J. F., \& Rowe, R. K. (2004). Influence of Landfill Leachate Suspended Solids on Clog (Biorock) Formation. Waste Management, 24, 723-738. https://doi.org/10.1016/j.wasman.2004.02.007

Venter, J. C., Remington, K., Heidelberg, J. F., Halpern, A. L., Rusch, D., Eisen, J. A., Wu, D., Paulsen, I., Nelson, K. E., Nelson, W., \& Fouts, D. E. (2004). Environmental Genome Shotgun Sequencing of the Sargasso Sea. Science, 304, 66-74.

https://doi.org/10.1126/science.1093857

Videla, H. A. (2018). Manual of Corrosion. New York: Routledge. https://doi.org/10.1201/9780203748190

Yoda, M., Kitagawa, M., \& Miyaji, Y. (1987). Long Term Competition between SulfateReducing and Methane-Producing Bacteria for Acetate in Anaerobic Biofilm. Water Research, 21, 1547-1556. https://doi.org/10.1016/0043-1354(87)90140-0

Young, R. A. (1993). The Rietveld Method (Vol. 5, pp. 1-38). International Union of Crystallography. 